\title{
ANALISIS KINERJA KEUANGAN PERUSAHAAN SEKTOR MANUFAKTUR AKIBAT KRISIS KEUANGAN AMERIKA
}

\author{
Candra Wijayangka \\ Prodi Administrasi Bisnis, Fakultas Komunikasi dan Bisnis, Universitas Telkom \\ email: wijayangka@gmail.com
}

\section{ABSTRAK}

Krisis keuangan Amerika pada tahun 2008 membawa dampak yang buruk bagi perekonomian Indonesia. Hampir semua sektor di Bursa Efek Indonesia terkena imbas, tidak terkecuali sektor manufaktur. Berbagai kebijakan dilakukan oleh perusahaan untuk meminimalisir risiko kebangkrutan, diantaranya adalah melakukan employee downsizing. Penelitian ini bertujuan untuk mengetahui perbedaan kinerja keuangan perusahaan sebelum dan setelah melakukan employeedownsizing pada perusahaan manufaktur yang terdaftar di Bursa Efek Indonesia (BEI) selama tahun 2006-2011.Perusahaan yang dijadikan sampel sebanyak 22 perusahaan yang melakukan employee downsizing diatas $13 \%$ periode 2008-2011. Data diolah dan dianalisis dengan menggunakan dua metode statistik, yaitu statistik deskriptif dan statistik induktif atau uji hipotesis. Metode yang digunakan adalah pengujian hipotesis t-test dua sampel yang berpasangan antara data sebelum dan sesudah melakukan employee downsizing dengan menggunakan rasio-rasio kinerja keuangan : NPM, ROA, dan ROE. Hasil penelitian menunjukkan adanya peningkatan kinerja keuangan perusahaan setelah melakukan employee downsizing jika dilihat menggunakan rasio ROA. Sedangkan jika dilihat melalui rasio NPM dan ROE. Penelitian ini menemukan adanya penurunan kinerja keuangan sesudah melakukan employee downsizing. Berdasarkan dari hasil uji analisis menunjukkan bahwa tidak terdapat perbedaan yang signifikan antara sebelum dan sesudah dilakukannya employee downsizing berdasarkan analisis rasio keuangan yang meliputi net profit margin, return on equity, dan returnon asset.

Kata kunci : Employee Downsizing, Net Profit Margin, Return On Assets, Return On Equity 


\section{Pendahuluan}

Krisis ekonomi yang terjadi pada tahun 2008 mengakibatkan terjadinya PHK massal. Tahun 2009 oleh API (Asosiasi Pengusaha Indonesia), diperkirakan akan terjadi PHK hingga 1,5 juta karyawan. Keadaaan perekonomian yang sering tidak menentu dan sulit diramalkan dewasa ini sangat berpengaruh terhadap kelangsungan hidup dunia usaha yang tetap ingin bertahan dan terus mengembangkan usahanya. Perubahan dalam perekonomian dan teknologi serta informasi telah membuat perusahaan-perusahaan harus menghadapi persaingan yang ketat, tidak hanya antar perusahaan dalam industri yang sejenis tetapi melibatkan industri secara keseluruhan, salah satunya pada industri manufaktur. Kurang kuatnya kinerja komoditas berbasis manufaktur ini tidak terlepas dari lemahnya dukungan kegiatan investasi setelah krisis.

Perusahaan yang memiliki sumber daya manusia yang kuat justru akan menerima dampak perubahan yang terjadi sebagai sebuah tantangan untuk tetap eksis bahkan menjadi suatu keuntungan bagi perusahaan. Akan tetapi bagi perusahaan yang sumber daya manusianya terbatas, perubahan tersebut direspon sebagai suatu ancaman. Ancaman ini akan direspon dengan berbagai kemungkinan, beberapa perusahaan merespon perubahan tersebut dengan melaksanakan strategi seperti pengurangan biaya promosi, menaikkan harga produk bahkan sampai pada pengurangan karyawan (downsizing) atau restrukturisasi dalam rangka meningkatkan daya saing dan pertumbuhan.

Downsizing adalah perubahan struktur yang dilakukan sebuah perusahaan dengan tidak mengurangi keefektifan produktifitas dari perusahaan itu sendiri untuk mengurangi jumlah tenaga kerja yang dianggap sudah tidak efektif atau bahkan jumlah unit operasi. Bahasa kasarnya ialah PHK. Ada beberapa penyebab yang menjadikan sebuah perusahaan melakukan downsizing :

1. Krisis ekonomi yang dialami oleh perusahaan.

2. Pendapatan perusahaan lebih kecil ketimbang pengeluaran.

3. Jumlah tenaga kerja yang terlampau banyak.

4. Butuh tenaga kerja yang lebih professional dan personalia yang baru.

5. Perusahaan ingin membuka cabang baru.

6. Pengendalian biaya operasional.

7. Meningkatkan keuntungan (profitability).

Pada dasarnya krisis ekonomi akan mengakibatkan penurunan penjualan pada produk yang dihasilkan oleh perusahaan, hal ini lama kelamaan akan membuat produksi terhambat, penerimaan perusahaan terhenti yang pada akhirnya akan mengakibatkan perusahaan tidak mampu membayar gaji karyawan sehingga terjadilah pengurangan karyawan (employee downsizing). Berikut ini digambarkan pada tabel 1.1 total penjualan pada perusahaan-perusahaan yang melakukan employee downsizing pada industri manufaktur yaitu sebanyak 22 perusahaan. 


\section{JURNAL}

MANAJEMEN

INDONESIA

Vol. 14. No. 2

Agustus 2014
Tabel 1 Perusahaan yang melakukan downsizing 2008-2009 serta perubahan sales

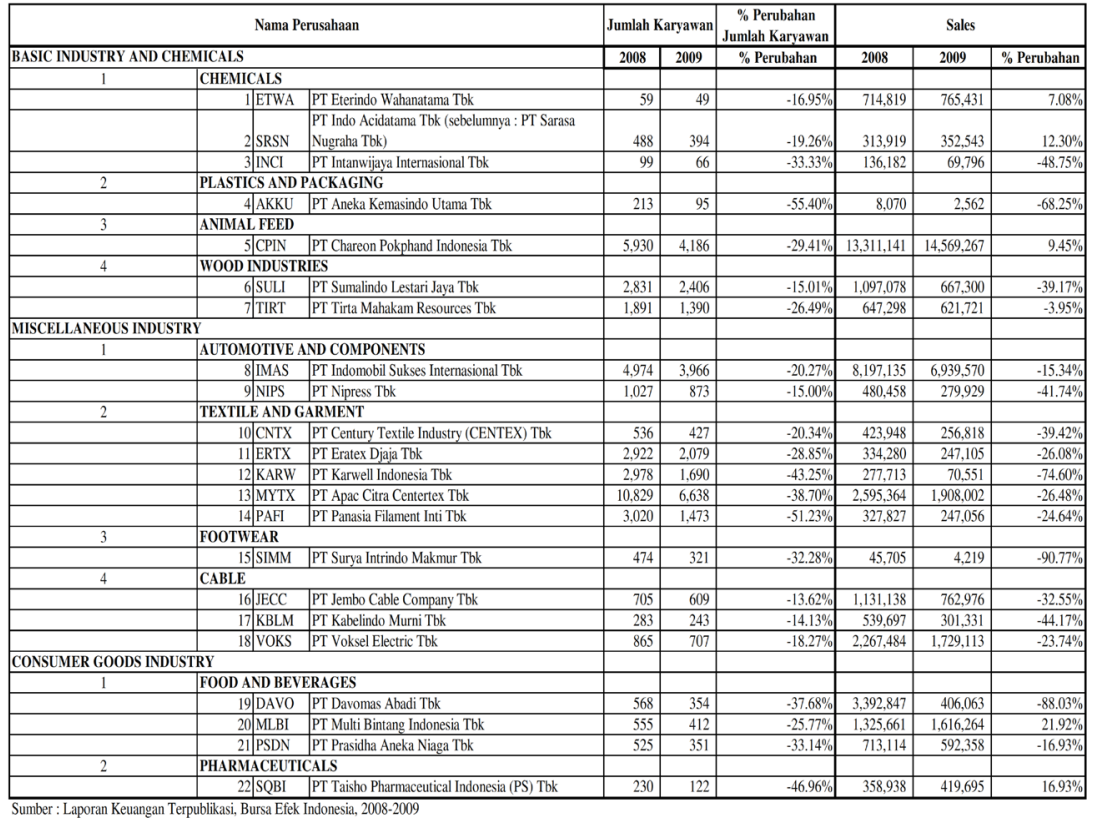

Berdasarkan tabel di atas hampir semua perusahaan yang melakukan downsizing pada tahun 2008-2009 mengalami penurunan jualan dimana rata-rata penurunannya adalah sebesar $28,95 \%$ yang pada akhirnya menyebabkan terganggunya kinerja keuangan perusahaan

Sesuai definisi yang dikemukakan oleh Appelbaum (2001), downsizing merupakan strategi bisnis yang didesain untuk meningkatkan kemampuan keuangan perusahaan dengan mengurangi dan merubah struktur tenaga kerja untuk meningkatkan hasil operasionalnya. Perusahaan memilih melakukan pengurangan jumlah karyawan sebagai langkah jangka pendek agar bisnis dapat berjalan dengan baik.

Menciutkan jumlah tenaga kerja tampaknya sudah menjadi gaya hidup dan tampilan banyak organisasi di dunia industri. Hasil yang diharapkan oleh manajemen saat mengambil keputusan employee downsizing adalah peningkatan pendapatan perusahaan atau kemampuan yang lebih besar untuk mengendalikan harga produk supaya lebih kompetitif dengan pesaingnya (Hillier, 2007). Dengan kata lain, tujuan dilakukannya employee downsizing adalah untuk meningkatkan kinerja keuangan perusahaan.

Untuk mengukur kinerja keuangan perusahaan dapat dilakukan dengan menggunakan rasio-rasio keuangan. Banyak sekali macam-macam rasio keuangan yang dikenal, salah satu yang cukup dikenal adalah Analisis Du Pont. Analisis Du Pont adalah suatu metode yang digunakan untuk menganalisis profitabilitas perusahaan dan tingkat pengembalian ekuitas. Analisis Du Pont sangat bermanfaat untuk memberikan gambaran tentang kondisi keuangan suatu perusahaan. Du Pont System merupakan analisis yang mencakup rasio aktivitas dan margin keuntungan atas penjualan dan menunjukan bagaimana rasio ini saling mempengaruhi untuk menentukan profitabilitas aktiva yang dimiliki perusahaan, juga dapat diketahui efisiensi atas penggunaan aktiva perusahaan. Analisis Du Pont merupakan salah satu cara untuk menilai efektifitas operasional perusahaan, dimana tujuan dari downsizing sendiri adalah untuk penghematan biaya operasional perusahaan. Sehingga dalam penelitian ini untuk melihat dampak dari employee downsizing terhadap kinerja keuangan perusahaan dilakukan dengan pendekatan sistem Du Pont.

Berdasarkan latar belakang permasalahan yang telah diuraikan diatas, maka pertanyaan penelitian yang dikemukakan adalah apakah terdapat perbedaan kinerja keuangan perusahaan antara sebelum dan sesudah melakukan employee downsizing. 
Sehubungan dengan latar belakang dan perumusan masalah yang telah diuraikan diatas, maka tujuan penelitian ini adalah menganalisis perbedaan kinerja keuangan perusahaan antara sebelum dan sesudah melakukan employee downsizing.

\section{Landasan Teori dan Metodologi \\ Employee Downsizing}

Downsizing merupakan strategi bisnis yang didesain untuk meningkatkan kemampuan keuangan perusahaan dengan mengurangi dan merubah struktur tenaga kerja untuk meningkatkan hasil operasionalnya (Appelbaum, 2001).

Pada umumnya downsizing merupakan respon manajemen atas beberapa kondisi seperti penggabungan usaha (merger) dan akuisisi, penurunan pendapatan dan pangsa pasar atas perubahan teknologi dan industri, implementasi struktur organisasi baru, keyakinan serta tekanan sosial yang menyatakan bahwa perusahaan dengan jumlah karyawan yang lebih sedikit akan lebih baik (Cummings \& Worley, 2001). Menurut Davis (2003), downsizing merupakan respon manajemen atas lingkungan bisnis global yang cepat berubah. Downsizing sebagai salah satu rencana manajemen strategik dapat meningkatkan efisiensi organisasi dengan cara mengelola secara fokus sebuah kompetensi utama yang dapat meningkatkan keunggulan bersaing dan meningkatkan atau dapat mengelola tingkatan pangsa pasar yang dimiliki oleh perusahaan.

Menurut Cumming dan Worley (2001), terdapat lima tahapan aplikasi untuk dapat menerapkan downsizing :

1. Tahapan pertama adalah mengklarifikasi strategi perusahaan. Apakah downsizing yang akan dilakukan telah sesuai dengan tujuan dan sasaran perusahaan.

2. Tahapan kedua adalah menilai berbagai pilihan dan memilih keputusan utama bagaimana downsizing akan dilakukan. Terdapat tiga metode downsizing berikut ini:

\section{a. Jangka Pendek : Pengurangan tenaga kerja}

Metode ini ditujukan untuk mengurangi jumlah tenaga kerja, implementasinya dilakukan dalam jangka pendek, dan dilakukan untuk mendorong terjadinya transisi dan transformasi.

Contoh : pengurangan karyawan (attrition), transfer karyawan, insentif pensiun, paket buyout, pemutusan hubungan kerja (layoffs).

b. Jangka Menengah : Mendesain ulang organisasi

Metode ini ditujukan untuk merubah organisasi perusahaan, implementasinya dilakukan dalam jangka menengah, dan dilakukan untuk mendorong terjadinya transisi dan transformasi.

Contoh : mengeliminasi fungsi organisasi, menggabungkan unit organisasi, mengeliminasi tingkatan manajemen, mengeliminasi produk perusahaan dan mendesain ulang tugas.

c. Jangka Panjang : Perubahan sistem

Metodeiniditujukanuntukmerubahbudayaperusahaan,implementasinyadilakukandalamjangkapanjang, dandilakukanuntukmendorongterjadinyatransformasi. Contoh : merubah tanggung jawab, melibatkan seluruh pihak-pihak yang terkait, mendorong terjadinya inovasi atau continuous improvement, simplifikasi dan downsizing yang dilakukan karena pilihan budaya perusahaan. 3. Tahapan ketiga adalah implementasi metode yang sudah dipilih untuk mengurangi ukuran perusahaan. Terdapat beberapa cara untuk menerapkan implementasi yang sukses, diantaranya adalah pengendalian downsizing sebaiknya dilakukan secara top to down karena keputusan tersebut merupakan keputusan sulit yang harus dibuat namun diharapkan tetap mengelola perspektif objektif dan menghindari natural instinct dari para individunya untuk melindungi fungsi dan perusahaan; mengidentifikasi area 


\section{JURNAL \\ MANAJEMEN \\ INDONESIA}

Vol. 14. No. 2

Agustus 2014 yang tidak efisien dan memiliki biaya tinggi; mempertahankan fokus strategi perusahaan yaitu dengan cara memberi pengertian bahwa aktivitas restrukturisasi merupakan bagian dari rencana untuk meningkatkan kinerja perusahaan, dan komunikasi yang merupakan kunci kesuksesan tercapainya tujuan perusahaan.

4. Tahapan keempat adalah mengatasi survivor syndrome, yaitu mengatasi implikasi tingkah laku pada tenaga kerja yang masih ada. Pada tahap ini, karyawan yang masih ada akan diminta untuk menambah tanggung jawabnya dan mempelajari pekerjaannya yang baru, seringkali dengan kenaikan kompensasi yang kecil atau tidak ada kenaikan sama sekali. Survivor syndrome meliputi perilaku yang berfokus pada dirinya dan cenderung menghindari resiko, sehingga dapat mengancam keberlangsungan perusahaan.

5. Tahapan kelima adalah pembaharuan dan pengembangan perusahaan dengan cara membuat strategi perusahaan yang baru atau melakukan modifikasi pada strategi yang sudah ada. Perusahaan seringkali gagal pada tahapan terakhir ini karena mereka tidak menginformasikan rencana pengembangan dan strategi pembaharuan dengan para karyawannya.

\section{Du Pont System}

Kinerja keuangan merupakan suatu hasil atas prestasi yang telah dicapai oleh perusahaan dalam menjalankan fungsinya dan pengelolaan dana perusahaan secara efektif dan efisien selama periode tertentu. Menurut Agnes Sawir (2003:1) kinerja keuangan adalah "suatu kondisi yang mencerminkan keadaan keuangan suatu perusahaan berdasarkan sasaran, standar, dan kriteria yang telah ditetapkan".

Pengukuran kinerja sangat dibutuhkan oleh perusahaan untuk mengetahui dan mengevaluasi sampai dimana tingkat keberhasilan perusahaan berdasarkan aktivitas-aktivitas yang telah dilaksanakan sebelumnya. Pengukuran kinerja dapat dilakukan dengan berbagai macam ukuran dan biasanya berdasarkan laporan keuangan perusahaan.

Mengetahui kinerja keuangan suatu perusahaan merupakan hal yang penting mengingat laporan keuangan merupakan sumber informasi bagi mereka yang berkepentingan termasuk lembaga pemberi kredit, diantaranya bank. Dengan laporan keuangan yang disusun oleh perusahaan dan dilampirkan ketika akan mengusulkan permohonan kreditnya, maka bank dapat mengolah informasi yang diberikan perusahaan sudah benar.

Dalam mengukur kinerja keuangan suatu perusahaan, Weston (2004) mengklasifikasikan ada 3 kelompok ukuran kinerja keuangan yaitu:

1. Ukuran kinerja

2. Ukuran efisiensi operasional

3. Ukuran kebijakan keuangan.

Ukuran-ukuran kinerja mencerminkan keputusan-keputusan strategis, operasi, dan pembiayaan. Strategi meliputi bidang-bidang keputusan yang penting seperti pemilihan daerah pemasaran produk, tempat perusahaan menjalankan operasinya, apakah akan menekankan penurunan biaya atau differensiasi produk, apakah akan memfokuskan pada area produk terpilih atau mencoba mencakup sekelompok besar pembeli potensial, dan sebagainya.

Ukuran efisiensi operasi mencerminkan pengelolaan penggunaan berbagai sumber daya yang dimiliki perusahaan dalam melaksanakan aktivitasnya seperti efisiensi sumber daya manusia. Sedangkan ukuran kebijakan keuangan mengukur sebatas mana total aktiva dibiayai oleh pemilik jika dibandingkan dengan pembiayaan yang disediakan oleh para kreditur. Selain itu dalam ukuran kebijakan keuangan juga mengukur kemampuan perusahaan dalam memenuhi kewajibannya.

Dari uraian para ahli mengenai kinerja keuangan dan pengelompokan ukuran kinerja keuangan yang dikemukakan oleh Weston, dalam pelaksanaannya melibatkan rasio-rasio keuangan sebagai instrumen khusus dalam menilai dan menganalisis suatu 
laporan keuangan pada suatu periode.

Banyak sekali macam-macam rasio keuangan yang dikenal dalam menganalisis kinerja sebuah perusahaan. Salah satu yang cukup dikenal adalah Analisis Du Pont. Menurut Gitman (2012) analisis system Du Pont adalah : "System used by management to dissect the firm's financial statement and to assess its finacial condition." Du Pont system digunakan sebagai alat diagnosa untuk menilai keadaan keuangan perusahaan. Sistem Du Pont menggabungkan laporan laba rugi dan neraca kedalam dua perhitungan yang menghitung tingkat profitabilitas, yaitu Return on Asset (ROA) dan Return on Equity (ROE). Gambar 2.1 menunjukkan Du Pont yang dimodifikasi, karena menghubungkan Return on Asset dari perusahaan dengan Return on Equity, dengan menggunakan Financial Leverage Multiplier (FLM). Bagian atas dari bagan merupakan ringkasan dari aktivitas operasi perusahaan yang tercermin pada laporan laba rugi, dan bagian bawah merupakan ringkasan dari neraca perusahaan.

\section{Metodologi}

Metode penelitian yang digunakan adalah deskriptif dan verifikatif. Jenis penelitian deskriptif yaitu dimulai dari pengumpulan, mengolah data hingga menyajikan hasil yang disertai interpretasi, sehingga akhirnya diperoleh gambaran yang jelas tentang pokok permasalahan yang diteliti. Penelitian verifikatif menggunakan pernyataan sementara atau dugaan yang akan diformulasikan ke dalam bentuk hipotesis yang harus diuji empirik.

\begin{tabular}{|c|c|c|c|c|c|}
\hline $\mathrm{NO}$ & Variabel & Konsep & Indikator & Ukuran & Skala \\
\hline 1 & \begin{tabular}{|l|} 
Net Profit Margin sebelum \\
employee downsizing (Xl.1) \\
Net Profit Margin sesudah \\
employee downsizing (Xl.2)
\end{tabular} & $\begin{array}{l}\text { Rasio yang digunakan untuk } \\
\text { mengukur laba bersih atas } \\
\text { penjualan }\end{array}$ & $\frac{\text { Earning after Tax }}{\text { Sales }} \times 100 \%$ & $\%$ & Rasio \\
\hline 2 & \begin{tabular}{|l|} 
Return on Assets sebelum \\
employee downsizing (X2.1) \\
Return on Assets sesudah \\
employee downsizing (X.2) \\
\end{tabular} & $\begin{array}{l}\text { Merupakan ukuran kemampuan } \\
\text { perusahaan didalam menghasiilkan } \\
\text { keuntungan (setelah pajak) bagi } \\
\text { perusahaan dengan memanfaatkan }\end{array}$ & $\frac{\text { Earning after Tax }}{\text { Total Assets. }} \times 100 \%$ & $\%$ & Rasio \\
\hline 3 & \begin{tabular}{|l|} 
Return on Equity sebelum \\
employee downsizing (X..1) \\
Return on Equity sesuldah \\
employee downsizing (X3.2)
\end{tabular} & 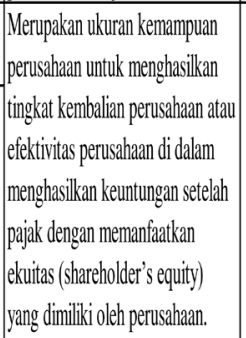 & $\frac{\text { Earning ofter Tax }}{\text { Total Equity }} \times 100 \%$ & $\%$ & Rasio \\
\hline
\end{tabular}

\section{Populasi dan Sampel}

Populasi dalam penelitian ini adalah perusahaan manufaktur yang terdaftar di Bursa Efek Indonesia (BEI) dan laporan keuangannya dipublikasikan di BEI pada tahun 2006-2011 yang berjumlah 133 perusahaan.

Penentuan sampel dilakukan secara purposive sampling, yaitu sampel perusahaan dipilih berdasarkan kriteria tertentu.

\section{Hasil dan Pembahasan}

Analisis Perbedaan Sebelum dan Sesudah Downsizing Net Profit Margin

Tabel 3. Paired Samples Test NPM

\begin{tabular}{|c|c|c|c|c|c|c|c|c|c|}
\hline \multirow{3}{*}{\multicolumn{2}{|c|}{ Paircd Samples Test }} & \multicolumn{5}{|c|}{ Paired Dillerences } & \multirow{3}{*}{$\mathrm{t}$} & & \multirow{3}{*}{$\begin{array}{l}\text { Sig. (2- } \\
\text { tailcd) }\end{array}$} \\
\hline & & \multirow[b]{2}{*}{ Mcan } & \multirow[b]{2}{*}{ Std. Deviation } & \multirow[b]{2}{*}{ Std. Error Mcan } & \multicolumn{2}{|c|}{$95 \%$ Confidenee Interval of the } & & & \\
\hline & & & & & Lowcr & Upper & & & \\
\hline
\end{tabular}


Pengujian terhadap hipotesis penelitian bertujuan untuk membuktikan perbe-

JURNAL

MANAJEMEN

INDONESIA

Vol. 14. No. 2

Agustus 2014 daan kinerja keuangan pada perusahaan sebelum dan sesudah melakukan downsizing. Pengujian dilakukan menggunakan uji beda 2 sampel berpasangan. Test pada $\infty=5 \%$. Variabel NPM yang diamati sebelum dan sesudah melakukan downsizing berbeda nyata terlihat dari nilai t-hitung $=1.480$ lebih kecil bila dibandingkan dengan t-tabel $(5 \%, 22-1)=1.721$, serta nilai $\mathrm{p}$-value $=0.077$ yang nilainya lebih besar bila dibandingkan dengan $\infty=5 \%(0.05)$. Hal tersebut menunjukkan hipotesis alternatif tidak dapat diterima. Sehingga dapat disimpulkan Net Profit Margin (NPM) pada perusahaan sesudah melakukan employee downsizing tidak lebih besar daripada Net Profit Margin (NPM) sebelum melakukan employee downsizing.

Return On Asset

Tabel 4. Paired Samples Test ROA

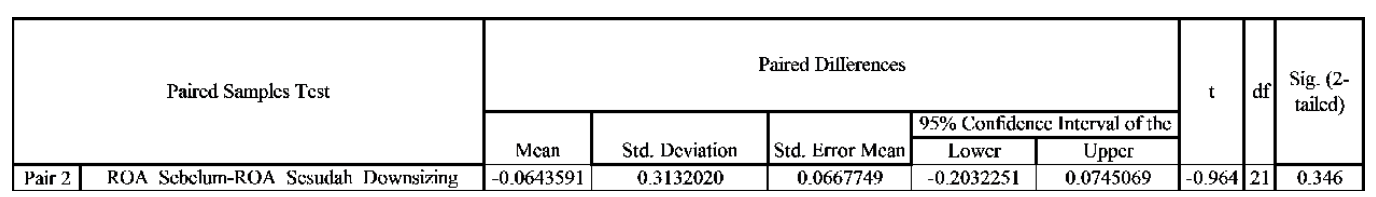

Variabel ROA yang diamati sebelum dan sesudah melakukan downsizing berbeda nyata terlihat dari nilai t-hitung $=-0.964$ lebih kecil bila dibandingkan dengan t-tabel $(5 \%, 22-1)=1.721$, serta nilai $\mathrm{p}$-value $=0.173$ yang nilainya lebih besar bila dibandingkan dengan $\infty=5 \%(0.05)$. Hal tersebut menunjukkan bahwa hipotesis alternatif tidak dapat diterima. Sehingga dapat disimpulkan Return On Assets (ROA) pada perusahaan sesudah melakukan employee downsizing tidak lebih besar daripada Return On Assets (ROA) pada perusahaan sebelum melakukan employee downsizing.

\section{Return On Equity}

Tabel 5. Paired Samples Test ROE

\begin{tabular}{|c|c|c|c|c|c|c|c|c|c|}
\hline \multirow{3}{*}{\multicolumn{2}{|c|}{ Paircd Samples Test }} & \multicolumn{5}{|c|}{ Paircd Differences } & \multirow{3}{*}{$\mathrm{t}$} & \multirow{3}{*}{ df } & \multirow{3}{*}{$\begin{array}{l}\text { Sig. (2- } \\
\text { tailcd) }\end{array}$} \\
\hline & & \multirow[b]{2}{*}{ Mean } & \multirow[b]{2}{*}{ Std. Deviation } & \multirow[b]{2}{*}{ Std. Error Mean } & \multicolumn{2}{|c|}{$95 \%$ Confidenee Interval of the } & & & \\
\hline & & & & & Lower & Upper & & & \\
\hline Pair 3 & ROF Schclum-ROГ: Sesudah Downsizing & 0.0767773 & 1.1777400 & 0.2510950 & -0.4454034 & 0.5989579 & 0.306 & 21 & 0.763 \\
\hline
\end{tabular}

Variabel ROE yang diamati sebelum dan sesudah melakukan downsizing berbeda nyata terlihat dari nilai t-hitung $=0.306$ lebih kecil bila dibandingkan dengan t-tabel $(5 \%, 22-1)=1.721$, serta nilai $\mathrm{p}$-value $=0.382$ yang nilainya lebih besar bila dibandingkan dengan $\infty=5 \%(0.05)$. Hal tersebut menunjukkan hipotesis alternatif tidak dapat diterima. Sehingga dapat disimpulkan Return On Equity (ROE) pada perusahaan sesudah melakukan employee downsizing tidak lebih besar daripada Return On Equity (ROE) pada perusahaan sebelum melakukan employee downsizing.

\section{Kesimpulan}

Berdasarkan hasil analisis pada bab sebelumnya, kesimpulan yang dapat ditarik dari hasil penelitian ini adalah :

1. Penelitian ini berhasil menemukan adanya peningkatan kinerja keuangan perusahaan setelah melakukan employee downsizing jika dilihat menggunakan rasio Return On Assets (ROA). Sedangkan jika dilihat melalui rasio Net Profit Margin (NPM) dan Return On Equity (ROE) penelitian ini menemukan adanya penurunan kinerja keuangan perusahaan setelah perusahaan melakukan employee downsizing.

Net Profit Margin

Rata-rata Net Profit Margin dari seluruh perusahaan sesudah melakukan downsizing mengalami penurunan dari $-3.91 \%$ menjadi $-21.95 \%$. 
Rata-rata Return On Assets sesudah melakukan downsizing mengalami peningkatan dari $0.16 \%$ menjadi $6.60 \%$. Peningkatan yang terjadi pada variabel ROA dapat mengindikasikan adanya efek yang positif dari adanya penerapan downsizing pada kinerja keuangan perusahaan. Efek positif ini memperlihatkan adanya kondisi yang baik bagi perusahaan dimana dengan pelaksanaan downsizing tersebut menyebabkan perusahaan mampu meningkatkan laba bersih sehingga mampu meningkatkan rasio profitabilitas perusahaan.

Return On Equity

Rata-rata Return On Equity dari seluruh perusahaan sesudah melakukan downsizing mengalami penurunan dari $1.52 \%$ menjadi $-6.16 \%$.

2. Dilihat dari hasil uji hipotesis, penelitian ini berhasil menemukan tidak adanya perbedaan pada kinerja keuangan perusahaan periode sebelum dan sesudah melakukan employee downsizing. Hal ini menunjukan bahwa dengan dilakukannya employee downsizing tidak mempengaruhi kemampuan perusahaan dalam mengelola aktivanya secara efektif untuk menghasilkan keuntungan, serta tidak pula mempengaruhi kemampuan perusahaan dalam menghasilkan keuntungan untuk jangka pendek.

\section{Daftar Pustaka}

Appelbaum, S.H. dan Donia, M. 2001. The Realistic Downsizing Preview : A Multiple Case Study, Part II: Analysis of RDP model: Results of Data Collected and Purposed New Model. Journal of Career Development International. MCB University Press 2001 : 193-211.

Brigham, Eugene F and Houston J.F. 2007. Essentials of Financial Management. United States of America: Thomson-South Western.

Bullon, F.M. and Bueno, M.J.S. 2010. Downsizing Implementation and Financial Performance. Journal of Management Decisions. Vol. 48 No. 8:1181-1197.

Cummings, T. dan Worley, J. 2001. Organization Development and Change (7th ed). South-Western College Publishing, Inc. Cincinnati, $\mathrm{OH}$.

Davis, J.A. 2003. Organizational Downsizing: A Review of Literature for Planning and Research. Journal of Healthcare Management. Vol. 48 No. 2 : 181-199.

De Meuse, K.P; Bergmann T.J; Vanderheiden P.A. and Roraff C.E. 2004. New Evidence Regarding Organizational Downsizing and a firm's Financial Performance : A Long-term Analysis. Journal of Managerial Issues. Vol. XVI Number 2 Summer $2004: 155-177$.

Fei Tsai-C and Fang Yen-Y. 2008. A Model to Explore the Mystery between Organizations' downsizing Strategies and Firm Performance. Journal of Organizational Change Management. Vol 21 No 3 : 367-381.

Gitman and Zutter. 2012. Principle of Managerial Finance. 13th Edition. Pearson, Addison Wesley.

Gyu, Chang Yu dan Sung Park Jong. 2006. The effect of downsizing on the financial performance and employee productivity of Korean firms. International Journal of Manpower. Vol. 27 No. $2: 230-250$.

Hillier, D.A; Marshall, P.M and Werema, S. 2007. Employee layoff, Shareholder Wealth and Firm Performance : Evidence from The UK. Journal of Business Finance \& Accounting. Vol 34 (3) \& (4) Apr 2007 : 467-494.

Husnan, Suad, dan Eny Pudjiastuti. 1998. Dasar-Dasar Manajemen Keuangan. Edisi Kedua. Yogyakarta: UPP AMP YKPN.

Lowe, K.B. 1998. Downsizing and firm performance : Panacea or Paradise Lost?. The Academy of Management Executive. Briarcliff Manor. Nov 1998. Vol. 12 No. $4: 130-132$.

Mirabal, M.S. Nell and DeYoung, R. 2005. Downsizing as a Strategic Intervention. 
The Journal of American Academy of Business. March 2005. Cambridge.

JURNAL

MANAJEMEN

INDONESIA

Vol. 14. No. 2

Agustus 2014
Nachrowi, D dan Usman, H. 2006. Pendekatan Populer dan Praktis Ekonometrika

Untuk Analisis Ekonomi dan Keuangan. Jakarta: LP-FEUI.

Nazir, Mohammad. 2005. Metode Penelitian. Bogor: Ghalia Indonesia.

Palepu, Healy and Bernard. 2004. Business Analysis \& Valuation Using Financial Statement. South-Western: Thomson Learning.

Radcliffe, V.S; Campbell, D.R and Fogarty, T.J. 2001. Exploring Downsizing: A Case Study on the Use of Accounting Information. Journal of Management Accounting Research. Vol 13, P-131.

Sawir, Agnes. 2003. Kebijakan Pendanaan dan Restrukturisasi Perusahaan. Jakarta: Gramedia Pustaka Utama.

Safri, S.H. 1999. Teori Akuntansi Laporan Keuangan. Jakarta: Bumi Aksara.

Sumodiningrat, Gunawan. 2007. Pengantar Ekonometrika. Yogyakarta: BPFE.

Supomo, Bambang dan Indriantoro, Nur. 1999. Metodologi Penelitian Bisnis untuk Akuntansi \& Manajemen. Yogyakarta: BPFE.

Weston, J.F. 2004. Dasar-dasar Manajemen Keuangan. Edisi Ketujuh. Jakarta: Erlangga.

Wijaya, T. 2011. Cepat Menguasai SPSS 19 Untuk Olah \& Interpretasi Data Penelitian dan Skripsi. Yogyakarta: Cahaya Atma.

Aquocha, 2011. Analisis Rasio. Melalui (http://aquocha.blogspot.com/2011/02/ laporan-keuangan-analisisratio.html).

http://www.pajak.net/blog/peraturan/ump2008.pdf (diakses 1 April 2013)

Syahnandia, G. 2012. Manfaat Analisis Laporan Keuangan. Melalui http:/gazelsyahnandia.wordpress.com/2012/12/16/pengertian-manfaat-analisis- laporan-keuangan-dan-tehnik-analisa-laporan-keuangan/ 